\title{
Acute Toxicity and Sublethal Effects Caused by a Commercial Herbicide Formulated with 2,4-D on Physalaemus albonotatus Tadpoles
}

\author{
L. M. Curi • P. M. Peltzer • M. T. Sandoval • \\ R. C. Lajmanovich
}

Received: 12 September 2018 / Accepted: 28 December 2018

(C) Springer Nature Switzerland AG 2019

\begin{abstract}
The aim of this study was to evaluate the acute and chronic effects caused by exposure to the 2,4 dichlorophenoxyacetic acid (2,4-D)-based commercial herbicide Amina Zamba® on Physalaemus albonotatus tadpoles from Gosner stage 25. The lethal concentration (LC50) was determined after exposure to different concentrations of Amina Zamba ${ }^{\circledR}$ (350 to $2400 \mathrm{mg} / \mathrm{L}$ ) at $96 \mathrm{~h}$. Sublethal effects were evaluated after chronic exposure to four fractions of the LC50 $96 \mathrm{~h}$ obtained (12.5, 25,50 , and $75 \%$ of LC50 $96 \mathrm{~h}$ ) and a control. The biological responses analyzed included survival, growth and development, morphological abnormalities, and histological changes in the liver. The LC50 values of Amina Zamba® at 48, 72, and $96 \mathrm{~h}$ were $1040.2,754.2$, and $350 \mathrm{mg} / \mathrm{L}$, respectively. The chronic exposure to the herbicide altered the survival of exposed tadpoles and caused several morphological abnormalities and liver histological alterations, mainly at the highest concentra-
\end{abstract}

L. M. Curi · P. M. Peltzer · R. C. Lajmanovich

Laboratorio de Ecotoxicología, Facultad de Bioquímica y Ciencias Biológicas, Universidad Nacional del Litoral (FBCB-UNL), Ciudad Universitaria, Paraje el Pozo s/n, CP: 3000 Santa Fe, Argentina

L. M. Curi $(\bowtie) \cdot$ P. M. Peltzer · R. C. Lajmanovich Consejo Nacional de Investigaciones Cientificas y Técnicas (CONICET), Buenos Aires, Argentina

e-mail: lucilacuri@gmail.com

M. T. Sandoval

Embriología Animal, Facultad de Ciencias Exactas y Naturales y Agrimensura, Universidad Nacional del Nordeste

(FaCENA-UNNE), Av. Libertad 5400, CP: 3400 Corrientes, Argentina tions tested. Oral disc malformations and intestinal abnormalities were the most frequent abnormalities in all treated tadpoles. Histological alterations observed in the liver structure included hepatocyte vacuolization, enlargement of sinusoids, dilation of blood vessels, and a significant increase in the number of melanomacrophages in tadpoles exposed to 25,50 , and $75 \%$ LC $50_{96 \mathrm{~h}}$ with respect to control $(P<0.05)$. Furthermore, the treated tadpoles showed an accelerated development rate, reaching Gosner stages 38 and 42 before controls. These results demonstrate that the chronic exposure to this commercial formulation affects the survival, accelerates metamorphosis, and induces morphological abnormalities and liver damage in P. albonotatus tadpoles.

Keywords Abnormalities · Herbicide · Histology Melanomacrophages $\cdot$ Tadpoles $\cdot$ Toxicity

\section{Introduction}

Amphibian populations are globally declining at alarming rates (Alford and Richards 1999; Stuart et al. 2004, 2008). This decline has been proposed to be caused by several factors, acting either alone or synergistically (Davidson and Knapp 2007; Mann et al. 2009). The intensification of agricultural activities and the contamination of the environment with pesticides, fertilizers, and other toxic chemical substances are among the most important pressures on aquatic ecological systems (Relyea and Hoverma 2006) and have been suggested 
to play important roles in this phenomenon (Carey and Bryant 1995; Davidson et al. 2002).

Anurans are among the groups most susceptible to pesticides, mostly due their particular ecological niche (Marco et al. 2001), which they are exposed to these contaminants during the aquatic or terrestrial stages of their life (Aronzon et al. 2011). The exposure to agricultural pesticides can be direct from broadcast spraying of fields or indirect as a product of leaching, runoff, or atmospheric deposition (Bruhl et al. 2013; Berger et al. 2013). The embryonic and larval stages of anurans are considered critical periods of development because cells, organs, and systems are differentiated and developed during this time (Storrs and Semlitsch 2008). For this reason, anuran tadpoles are considered good indicators of environmental health (Wake and Vredenburg 2008).

Pesticides such as atrazine, chlorpyrifos, glyphosate, and carbaryl alter different biological processes, such as growth (Metts et al. 2005; Widder and Bidwell 2008), development and metamorphosis (Hayes and Wu 1995; Boone 2008), reproduction (Hayes et al. 2002, 2003, 2006a; Sánchez et al. 2014), metabolism (Attademo et al. 2007, 2015; Lajmanovich et al. 2011), and behavior (Punzo 2005; Relyea 2005; Teplitsky et al. 2005). Endocrine disruption is also caused by atrazine (Hayes et al. 2003), and genomic damages are caused by flurochloridone-based herbicides or agricultural pond eutrophication in anurans species (Nikoloff et al. 2014; Peltzer et al. 2008, respectively). On the other hand, some environmental pollutants used in the agricultural activities are known to affect the immune system of amphibians (Hayes et al. 2006b; Jantawongsri et al. 2013).

Melanomacrophages (MMs) play an important role in the immunological response and detoxification of pollutants (Van der Oost et al. 2003). MMs are present in the liver and are able to produce and store pigment in their cytoplasm and participate in the destruction, detoxification, and recycling of endogenous and exogenous materials (Agius and Roberts 2003; Passantino et al. 2013). Diverse studies have demonstrated that the number of MMs increases after exposure to toxic substances (Loumbourdis and Vogiatzis 2002; Paunescu et al. 2010; Bach et al. 2018); thus, they may be useful as biomarkers of environmental pollution.

The 2,4 dichlorophenoxyacetic acid (2,4-D) is an active ingredient used in diverse commercial formulations and one of the most widely used herbicides in the world (Wauchope et al. 1992). It is a selective postemergence herbicide used for the control of broadleaf weed species in a variety of food/feed sites, including field, fruit, and vegetable crops (USEPA 2005). In aerobic aquatic environments, the half-life of 2,4-D is approximately 15 days (USEPA 2005; Wilson et al. 1997). Due to its high water solubility and low soil adsorptivity, some 2,4-D can be expected to reach surrounding surface waters (Waite et al. 2002).

The 2,4-D herbicides modifies the cell-wall plasticity and causes abnormal increases in the biosynthesis of proteins and ethylene, resulting in an uncontrolled cell division that produces an overstimulation of growth, damage of the vascular tissue, and final death of plants (Zimdahl 1993). With few exceptions, the effects and toxicity of the salt and ester forms of 2,4-D are quite similar to those of the acid form (USEPA 2005). However, it is important to note that the "inert ingredients" in commercial pesticide formulations of 2,4-D could affect its toxicity, either additively or synergistically (Dann 2009). 2,4-D has been classified as Class II (moderately hazardous) by the World Health Organization (2009) and as possibly carcinogenic to humans by the International Agency for Research on Cancer (IARC 2015). The toxicity of 2,4-D has been reported in different organisms like birds, small invertebrates, fish, frogs, reptiles, and algae (Oztas et al. 2011; Marcato et al. 2017). It can cause low growth rates, reproductive problems, changes in behavior, or death in non-target species (Charles et al. 2001; Rodriguez and Amín 1991). In addition, 2,4-D has the potential to induce the expression of vitellogenin in males and juveniles of Oncorhynchus mykiss and to cause endocrine disruption effects (Xie et al. 2005). Several studies have also demonstrated that 2,4-D affects the survival of Rana sphenocephala (Ryan et al. 2007), blocks the maturation of oocytes in Xenopus laevis (Stebbins-Boaz et al. 2004), and causes reduction in body size and delay of development and produces microcephaly and agenesis of gills in early embryonic development of Rhinella arenarum (Aronzon et al. 2011). In adults of Rhinella arenarum, dermal exposure to 2,4-D induces glutathione Stransferase activity and significantly higher DNA damage (Lajmanovich et al. 2015).

The aim of this study was to evaluate the acute lethality and sublethal effects (growth and development, morphological abnormalities, and alterations in liver histology) caused by chronic exposure to the commercial herbicide 2,4-D Amina Zamba ${ }^{\circledR}$ on Physalaemus 
albonotatus (Anura: Leptodactylidae) tadpoles under laboratory conditions. The results may be useful to recognize biological alterations that allow predicting the presence of environmental contaminants and their potential risk to amphibian populations in agricultural areas.

\section{Methods}

\subsection{Test Organism and Biological Samples}

Physalaemus albonotatus (Anura: Leptodactylidae) was used as test organism, because several of its characteristics make it suitable for ecotoxicological studies (Hailey et al. 2006). This species has an extensive distribution range in South America and is commonly found in agricultural ponds in northeastern Argentina. Its conservation status is "Last Concern" (IUCN 2017). Foam nests $(n=2)$ from P. albonotatus were collected from a temporary pond from the surroundings of the University Campus of the Universidad Nacional del Nordeste $\left(27^{\circ} 28^{\prime} 4^{\prime \prime} \mathrm{S}, 58^{\circ} 46^{\prime} 58^{\prime \prime} \mathrm{W}\right)$ (Corrientes, Argentina) in February 2013 and transported to the laboratory. The collection was made with authorization of the Dirección de Recursos Naturales de la provincia de Corrientes (Res. $\mathrm{N}^{\circ}$ 845). At the laboratory, embryos and tadpoles were maintained in plastic containers $(30 \mathrm{~cm}$ wide $\times 20 \mathrm{~cm}$ high $\times 40 \mathrm{~cm}$ long) with dechlorinated tap water at $25^{\circ} \pm 1{ }^{\circ} \mathrm{C}$ and $16 / 8 \mathrm{~h}$ of light/dark photoperiod cycle. The tadpoles were fed $\mathrm{ad}$ libitum (once a day) with boiled lettuce until they reached Gosner stage (GS) 25-26 (Gosner 1960). The egg clutches were collected in two consecutively weeks, in the same site. One group was used for the acute toxicity test and the other for the chronic assay.

\subsection{Test Chemical}

The commercial formulation used was 2,4-D Amina Zamba® $(48.5 \% \mathrm{w} / v$ of active ingredient, dimethylamine salt of 2,4-dichlorophenoxyacetic acid; CAS 2008-39), supplied by Ciagro S.A., Argentina. It is a post-emergent selective systemic herbicide, with a recommended application field ratio of 0.40 to $1.5 \mathrm{~L} / \mathrm{h}$. To confirm the concentration of 2,4-D in the commercial formulation, we used high performance liquid chromatography (Waters 1525 Binary HPLC Pump) with a UV detector (Waters 2489 UV/Visible Detector), using an analytical column of C18 reverse phase (SUPELCOSILTM LC$18-4.6 \times 250 \mathrm{~mm})$. Acetonitrile $(70 \%)$ and water $(30 \%)$ were used as the mobile phases and the herbicide separation was performed at a flow rate of $0.75 \mathrm{~mL} \mathrm{~min}^{-1}$ and $25^{\circ} \mathrm{C}$. The fixed-wavelength UV absorbance detector was set at $236 \mathrm{~nm}$, and the injection volume was $20 \mu \mathrm{L}$. The limit of detection was $\pm 3 \mathrm{mg} / \mathrm{L}$. The stability of the different 2,4-D test solutions was analyzed at the beginning and at the end of the assay, following Peltzer et al. (2008, 2013). The error between nominal and measured concentrations did not exceed $5 \%$.

\subsection{Acute Toxicity Assay}

Due to the unavailability of lethal concentration (LC50) values of 2,4-D for $P$. albonotatus in the literature, a range-finding test was conducted based on information about 2,4-D toxicity in anuran species (Coady et al. 2013; Figueredo and Rodriguez 2014; Morgan et al. 1996; USEPA 2005) to determine the nominal concentrations used in the definitive acute assay. Tadpoles at GS $25 \pm 2$ were randomly selected and either exposed to 350,700 , 1400 , and $2400 \mathrm{mg} / \mathrm{L}$ of 2,4-D Amina Zamba® or kept in dechlorinated water (control) for $96 \mathrm{~h}$. Ten tadpoles were placed in triplicate $(N=30)$ in covered $10-\mathrm{cm}$ diameter Petri dishes containing $50 \mathrm{~mL}$ of the test solutions. The assay was conducted at $25 \pm 1{ }^{\circ} \mathrm{C}$ and $16 / 8 \mathrm{~h}$ of light/dark photoperiod cycle, and the tadpoles were not fed during the assay. Mortality was recorded and the test solutions were renewed every day.

\subsection{Chronic Toxicity Assay}

The test concentrations were calculated based on criteria of Figueredo and Rodriguez (2014) and corresponded to $0,12.5,25,50$, and $75 \%$ of the $\mathrm{LC} 0_{96 \mathrm{~h}}$ value estimated in the acute toxicity assay. Tadpoles at GS $25 \pm 2$ were randomly selected and either exposed to $43.7,87.5,175$, or $262.5 \mathrm{mg} / \mathrm{L}$ of 2,4-D Amina Zamba ${ }^{\circledR}$ or kept in dechlorinated water (control) for 49 days. Thirty tadpoles were placed in duplicate $(N=60)$ in plastic containers containing $1 \mathrm{~L}$ of the test solutions. The chronic assay was conducted at $25 \pm 1{ }^{\circ} \mathrm{C}$ and $16 / 8 \mathrm{~h}$ of light/ dark photoperiod cycle. The tadpoles were fed $\mathrm{ad}$ libitum with blended lettuce and the test solutions were renewed every $48 \mathrm{~h}$. The tadpoles that did not reach GS 46 at the end of the assay were maintained separately in 
$200 \mathrm{~mL}$ Petri dish with the same solution until complete metamorphosis.

\subsection{Biological Endpoints}

\subsubsection{Survival}

The survival of tadpoles in each treatment was recorded every $24 \mathrm{~h}$ and was expressed as percentage taking into account the two replicates. The survival was analyzed until day 34 , taking into account the decrease of survival $(80 \%)$ in chronic bioassay.

\subsubsection{Morphology and Development}

Every 7 days, two tadpoles of each concentration were randomly selected and euthanized by immersion in a $0.1 \%$ tricaine methanesulfonate solution (MS-222) buffered to $\mathrm{pH} 7.8$ with $\mathrm{NaHCO}_{3}$. Tadpoles were fixed in Bouin's fixative solution for $24 \mathrm{~h}$, and stored in alcohol $70 \%$ to preserve structures. All preserved specimens were staged according to the Gosner table. The snoutvent length (SVL) and total length (TL) were measured using a digital caliper $(0.01 \mathrm{~mm}$ precision $)$ and the body weight (BW) was measured using an electronic balance (0.01 g precision). The time to reach GS 38-39 (present and well-formed hind limbs), GS 42 (four limbs and tail present), and GS 45-46 (end of metamorphosis) was recorded taking into account at least $30 \%$ of individuals.

\subsubsection{Body and Visceral Abnormalities}

Each preserved specimen was examined for morphological abnormalities with a Leica EZ4 stereo-microscope equipped with a Canon EOS Rebel T3i digital camera. Oral disc malformations, abdominal edema, intestinal abnormalities (gut uncoiling, diverted gut), decreased pigmentation, and altered body shape were determined according to Krishnamurthy and Smith (2011), Lenkowski et al. (2008), and Peltzer et al. (2013).

\subsubsection{Liver Histology}

For the histological analysis of the liver, two fixed tadpoles at GS 39-45 from each concentration and the control $(N=10)$ were processed according the conventional histological procedures. Their whole body was dehydrated in an ethanol series, impregnated in a butyl alcohol-paraffin mixture, embedded in paraffin, serially sectioned at 4-5 $\mu \mathrm{m}$, and stained with hematoxylin-eosin. The sections were observed with a Leica DM500 optical microscope equipped with a Leica ICC50HD digital camera. Six micrographs ( $\times 40$ magnification) of nonconsecutive and randomly hepatic sections of each specimen per treatment were analyzed. Hypervascularization (congestion), enlargement of sinusoids, dilation of blood vessels, hepatocyte vacuolization, and necrosis were determined according to Cakici (2015) and Sayed and Younes (2017). The Image Pro Plus (Media Cybernetics, Inc. version 6.0) was used to quantify the number of MMs based on the different color observed in the histological liver parenchyma, stained with hematoxylin-eosin (Santos et al. 2014).

\subsection{Statistical Analyses}

The LC50 values and their respective 95\% confidence limits were calculated at 48, 72, and $96 \mathrm{~h}$, using the Trimmed Spearman-Karber method (Hamilton et al. 1977). For each statistical analysis, the KolmogorovSmirnov test and Levene test were performed to assume the normality and homogeneity of variance, respectively (Zar 1999). The Chi-square test $\left(\mathrm{X}_{2}\right)$ was used to compare the proportion of surviving tadpoles in each treatment (Peltzer et al. 2013) at day 34. A multivariate analysis of covariance (MANCOVA) was used to determine whether there were significant overall differences in SVL, TL, and BW between treatments, using GS as covariable. Then, univariate analysis of variance (ANOVA) was used to elucidate which biological responses contributed to a significant multivariate response. The prevalence of each type of abnormality was calculated by dividing the number of tadpoles with this abnormality by the number of individuals examined (Peltzer et al. 2013). ANOVA was also used to compare the number of MMs in the hepatic section and detect differences between treatments. Analyses were conducted using InfoStat/P version 1.1 (Grupo InfoStat Professional, Facultad de Ciencias Agrarias, Universidad Nacional de Córdoba, Argentina) and Sigmaplot v.11.0 (Systat Software).

\section{Results}

\subsection{Acute Toxicity}

The trimmed Spearman-Karber method allowed determining the LC50 values of 2,4-D Amina Zamba ${ }^{\circledR}$ 
for P. albonotatus tadpoles at GS 25. The LC50 values at 48,72 , and $96 \mathrm{~h}$ were as follows: 1040.2 (950.3-1138.5), 754.2 (551.8-1030.8), and $350 \mathrm{mg} /$ L (n.c.), respectively. These values demonstrated that tadpole mortality was dependent on the herbicide exposure time.

\subsection{Biological Endpoints in the Chronic Assay}

\subsubsection{Survival}

The results regarding the survival of tadpoles chronically exposed to the herbicide are summarized in Fig. 1. Until day 13 of exposure, no mortality was recorded at the different concentrations tested or the control. After 21 days of exposure, an important decrease in survival was recorded at $87.5,175$, and $262.5 \mathrm{mg} / \mathrm{L}$ of $2,4-\mathrm{D}$ Amina Zamba ${ }^{\circledR}$ compared to the control, with significant differences between treatments up to day $34\left(\mathrm{X}_{2}=\right.$ $50.62, \mathrm{df}=3, P<0.0001)$. At 34 days of exposure, the survival at the highest concentration tested was $0 \%$, while that of control was about $80 \%$.

Fig. 1 Survival percentages of $P$. albonotatus tadpoles exposed to 2,4-D Amina Zamba ${ }^{\circledR}$ from GS 25. Note the gradual decrease of survival from day 13 to day 34

\subsubsection{Morphology and Development}

The MANCOVA performed with the SVL, TL, and BW of tadpoles showed no significant differences between the treatments and control, either with GS (Wilks' Lambda $=0.660, \mathrm{~F}=1.015, P=0.445)$ or time of exposure as covariable (Wilks' Lambda $=0.625, \mathrm{~F}=1.204$, $P=0.295)$. Figure 2 shows the mean SVL and TL and BW values of tadpoles (GS 25 to 38) exposed to 2,4-D Amina Zamba ${ }^{\circledR}$, as compared with those of the control. The differences were not statistically significant (SVL: $\mathrm{F}=2.238, \mathrm{df}=4, P=0.089 ; \mathrm{TL}: \mathrm{F}=0.717, \mathrm{df}=4, P=$ 0.587; $\mathrm{BW}: \mathrm{F}=1.879, \mathrm{df}=4, P=0.141)$.

The results regarding the time at which at least $30 \%$ of tadpoles reached GS 38-39, 42, and 45-46 (end of metamorphosis) are summarized in Fig. 3. The tadpoles treated with 43.7 and $87.5 \mathrm{mg} / \mathrm{L}$ 2,4-D Amina Zamba ${ }^{\circledR}$ were the first to reach GS 38-39 around day 28 of the experiment. The tadpoles treated with $87.5 \mathrm{mg} / \mathrm{L}$ of herbicide were the first to reach GS 42 around day 40 of the experiment. Besides, the control tadpoles reached GS 38-39 (45 days) and GS 42 (52 days) later than treated tadpoles. The first individuals that reached GS

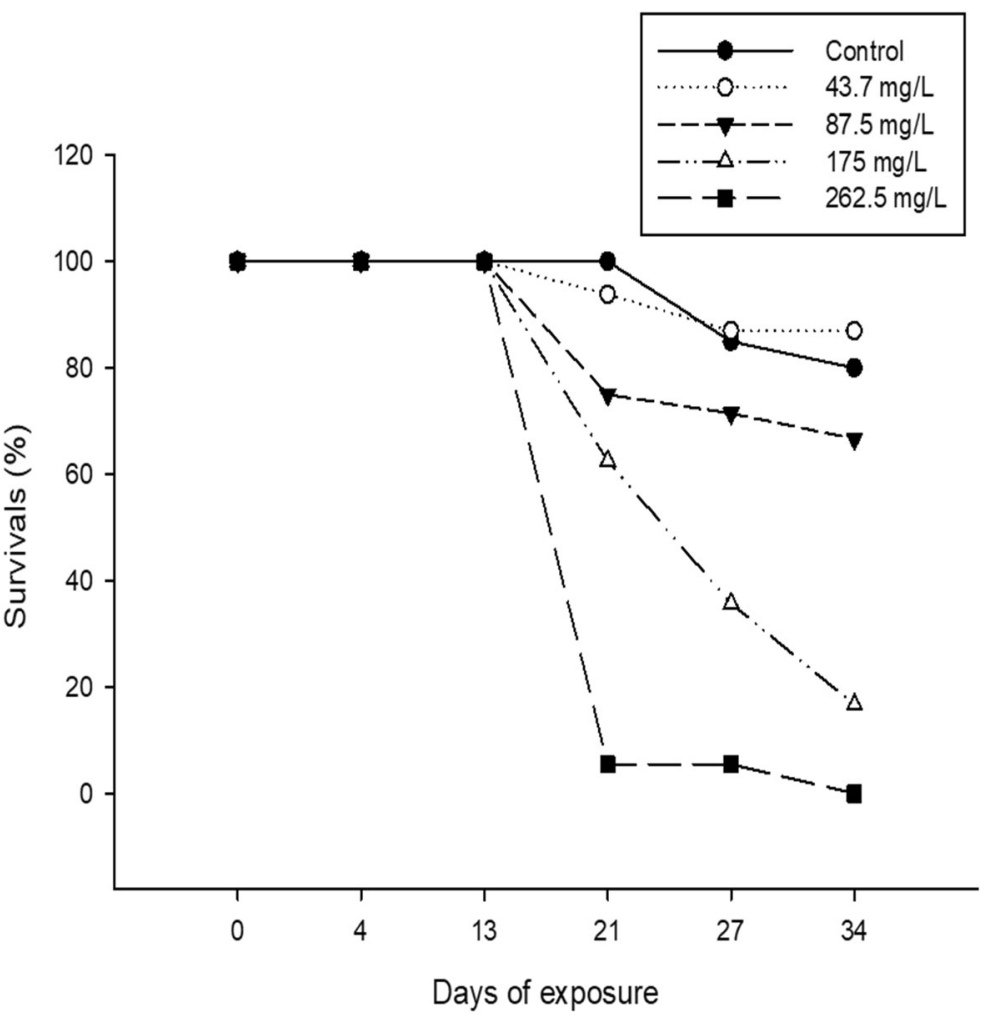




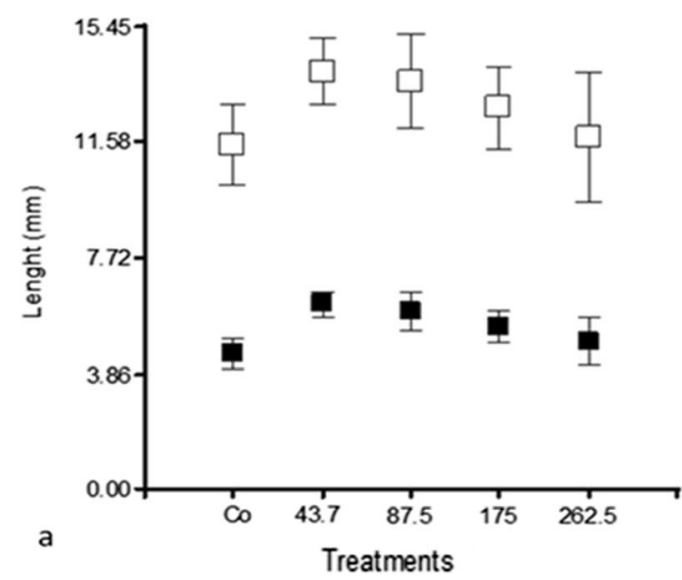

Fig. 2 Morphological endpoints of $P$. albonotatus tadpoles exposed to $43.7,87.5,175$, and $262.5 \mathrm{mg} / \mathrm{L}$ of 2,4-D Amina

45-46 (end of metamorphosis) were the tadpoles exposed to 43.7 and $87.5 \mathrm{mg} / \mathrm{L}$ of herbicide on day 45 . The control tadpoles reached GS 45-46 around day 53. The tadpoles exposed to $262.5 \mathrm{mg} / \mathrm{L}$ of herbicide did not survive further than GS 42, and the mean time to reach metamorphosis could not be estimated.

\subsubsection{Abnormalities}

The morphological abnormalities observed in P. albonotatus tadpoles exposed to 2,4-D Amina

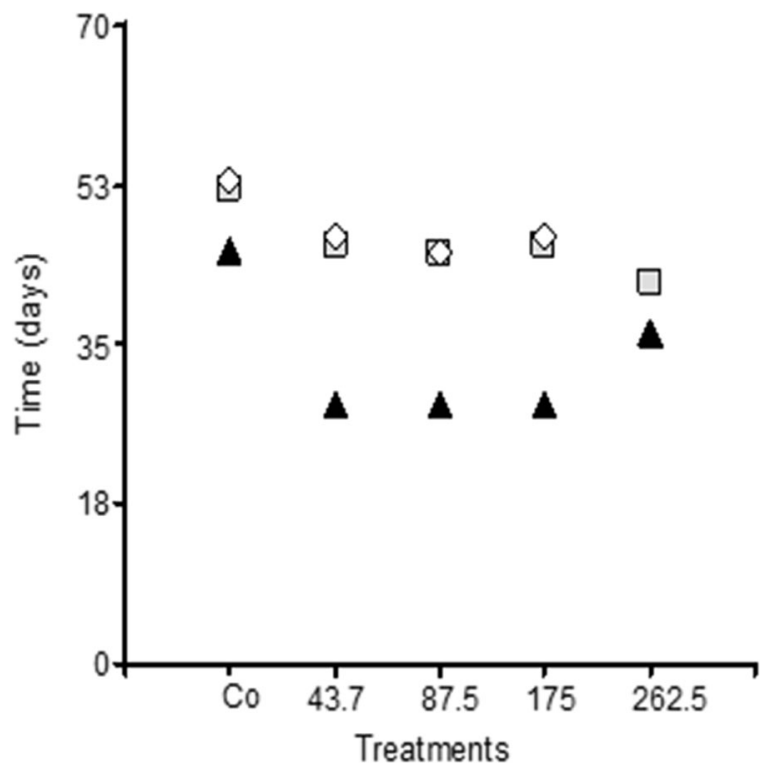

Fig. 3 Time required (days) to reach GS 38 (triangle), GS 42 (square), and GS 45-46 (rhombus) of $P$. albonotatus tadpoles exposed to 2,4-D Amina Zamba ${ }^{\circledR}$ and control (Co). For $262.5 \mathrm{mg} / \mathrm{L}$, this value was not available

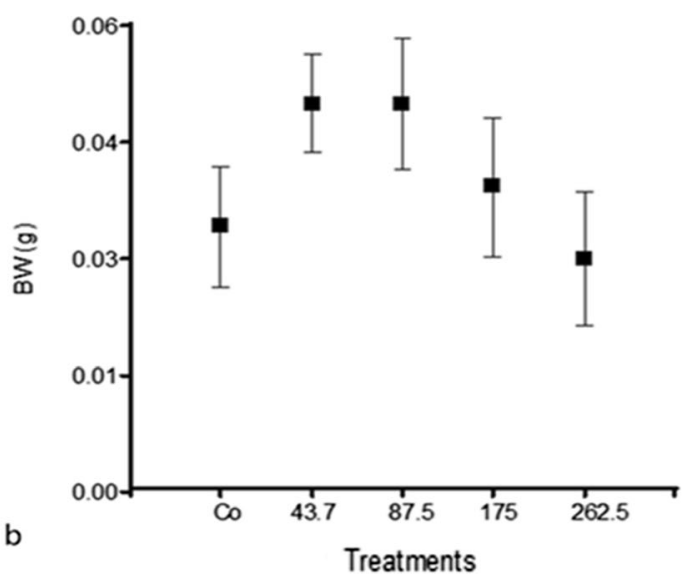

Zamba ${ }^{\circledR}$ and control (Co). a Mean \pm standard error of SVL (black bar) and TL (white bar); b mean \pm standard error of BW

Zamba ${ }^{\circledR}$ were as follows: decreased pigmentation, malformations of the oral disc, intestinal abnormalities (uncoiling intestine), abdominal edema, and altered body shape (Fig. 4). The malformations of the oral disc consisted of loss of the anterior tooth rows and upper jaw sheath (Fig. 4d) or loss of the first anterior tooth row and partial loss of the posterior tooth rows (Fig. 4e). The prevalence values of each type of abnormality are summarized in Table 1.

\subsubsection{Liver Histology}

The hepatic tissue of control individuals presented normal histoarchitecture, with hepatocytes forming cords surrounded by sinusoids, scattered blood vessels, and some isolated MMs (Fig. 5a, b). In contrast, the liver of treated tadpoles showed enlargement of hepatic sinusoids (in all treatments), hypervascularization (in 175 and $262.5 \mathrm{mg} / \mathrm{L}$ ), dilation of blood vessels, and vacuolization of hepatocytes (in 87.5, 175 and $262.5 \mathrm{mg} / \mathrm{L}$ ) (Fig. 5c-f). The ANOVA showed significant differences in the mean number of MMs in the liver of treated tadpoles and control $(\mathrm{F}=8.86, \mathrm{df}=4 ; P=$ $0.000)$. The number of MMs of tadpoles treated with 87.5, 175 , and $262.5 \mathrm{mg} / \mathrm{L}$ of 2,4 D Amina Zamba ${ }^{\circledR}$ was significantly higher than that of control (Dunnet post test $P<0.05$, Fig. 6).

\section{Discussion}

Most of 2,4-D addition to the environment results from effluents and spills resulting from its 

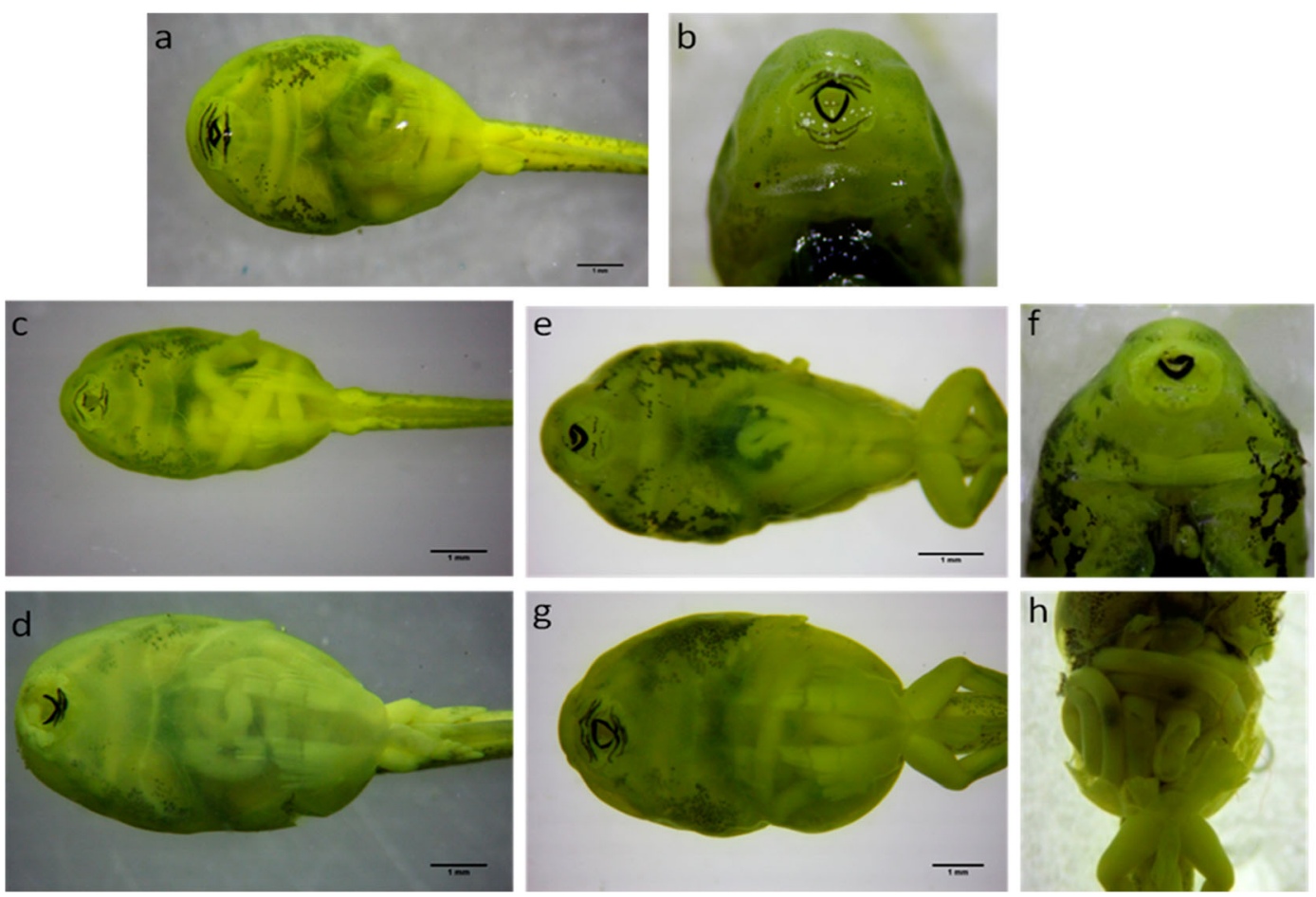

Fig. 4 Morphological abnormalities in P. albonotatus tadpoles exposed to 2,4-D Amina Zamba® and control. a General view and $\mathbf{b}$ detail of oral disc from a control tadpole; $\mathbf{c}$ intestinal abnormality (uncoiling) and $\mathbf{d}$ malformation of oral disc (loss of anterior tooth rows and upper jaw sheath) of tadpoles exposed to $87.5 \mathrm{mg} / \mathrm{L}$ 2,4-D Amina Zamba®; e loss of the first anterior tooth

manufacture and transportation or directly through its applications as a herbicide (Islam et al. 2018). After its application, a large amount of herbicide could be lost to the environment by runoff events due to its water solubility and low soil adsorptivity (Franco and Trapp 2010; Gonzalez et al. 2016). The

Table 1 Prevalence of abnormalities in P. albonotatus tadpoles exposed to 2,4-D Amina Zamba® and control. References: AE, abdominal edema; BSA, body shape altered; DP, decreased pigmentation; IA, intestinal abnormalities; MOD, malformations of oral disc

Prevalence of abnormalities

\begin{tabular}{lllllll}
\cline { 2 - 6 } & Total & Co & 43.7 & 87.5 & 175 & 262.5 \\
\hline MOD & 0.14 & - & - & 0.33 & 0.33 & 0.2 \\
LA & 0.19 & - & 0.33 & 0.22 & 0.33 & 0.2 \\
DP & 0.02 & - & - & 0.11 & - & - \\
BSA & 0.02 & - & - & - & 0.11 & - \\
AE & 0.04 & - & - & 0.22 & - & - \\
\hline
\end{tabular}

row and partial loss of posterior tooth rows, body shape altered, and $\mathbf{f}$ detail of the oral disc of tadpoles exposed to $175 \mathrm{mg} / \mathrm{L} \mathrm{2,4-D}$ Amina Zamba ${ }^{\circledR}, \mathbf{g}$ general view of intestinal abnormality (uncoiling) of tadpoles exposed to $262.5 \mathrm{mg} / \mathrm{L}$ 2,4-D Amina Zamba ${ }^{\circledR}$ and $\mathbf{h}$ detail of the uncoiling of the intestine. Note that the colors of the tadpoles are due the Bouin fixation. Scale: $1 \mathrm{~mm}$

potential risk of herbicide residue contamination depends on the runoff rate (Islam et al. 2018).

In agricultural areas of Canada, the highest concentration of 2,4-D reported in surface water was $345 \mathrm{ng} / \mathrm{L}$, whereas in agricultural and urban mixed sites, it was $1230 \mathrm{ng} / \mathrm{L}$ (Woudneh et al. 2007). After direct application in crop fields, the values detected were as high as $50 \mathrm{mg} / \mathrm{L}$ (World Health Organization 1989; Lilienfeld and Gallo, 1989). A study in 19 urban rivers across Canada showed a mean concentration of 2,4-D of 172 ng/L (Glozier et al. 2012). The Canadian Environmental Water Quality Guidelines for the Protection of Aquatic Life (2014) indicates that a concentration of $4 \mu \mathrm{g} / \mathrm{L}$ of $2,4-\mathrm{D}$ is the maximum level allowed in freshwater to protect the aquatic life. It is important to remark that the reported concentrations in the environment are below the levels known to cause effect in amphibians and fish (Coady et al. 2013). In South America, the information about 2,4-D levels in surface waters is scarce (Palma et al. 2004). Particularly, in Argentina, no data about the real concentration of 2,4- 
Fig. 5 Liver histological section of $P$. albonotatus tadpoles exposed to 2,4-D Amina Zamba® and control. a, b Control; c $87.5 \mathrm{mg} / \mathrm{L} ; \mathbf{d} 175 \mathrm{mg} / \mathrm{L} ; \mathbf{e}, \mathbf{f}$ $262.5 \mathrm{mg} / \mathrm{L}$. References: hepatic sinusoids (s), hepatocytes (h), hypervascularization (hip), blood vessels $(\mathrm{Bv})$, vacuolization of hepatocytes (asterisk), melanomacrophages (black arrow), erythrocytes (head arrow). a, c-e $(\times 40$ magnification, scale $20 \mu \mathrm{m}), \mathbf{b}, \mathrm{f}(\times 100$ magnification, scale $10 \mu \mathrm{m}$ )
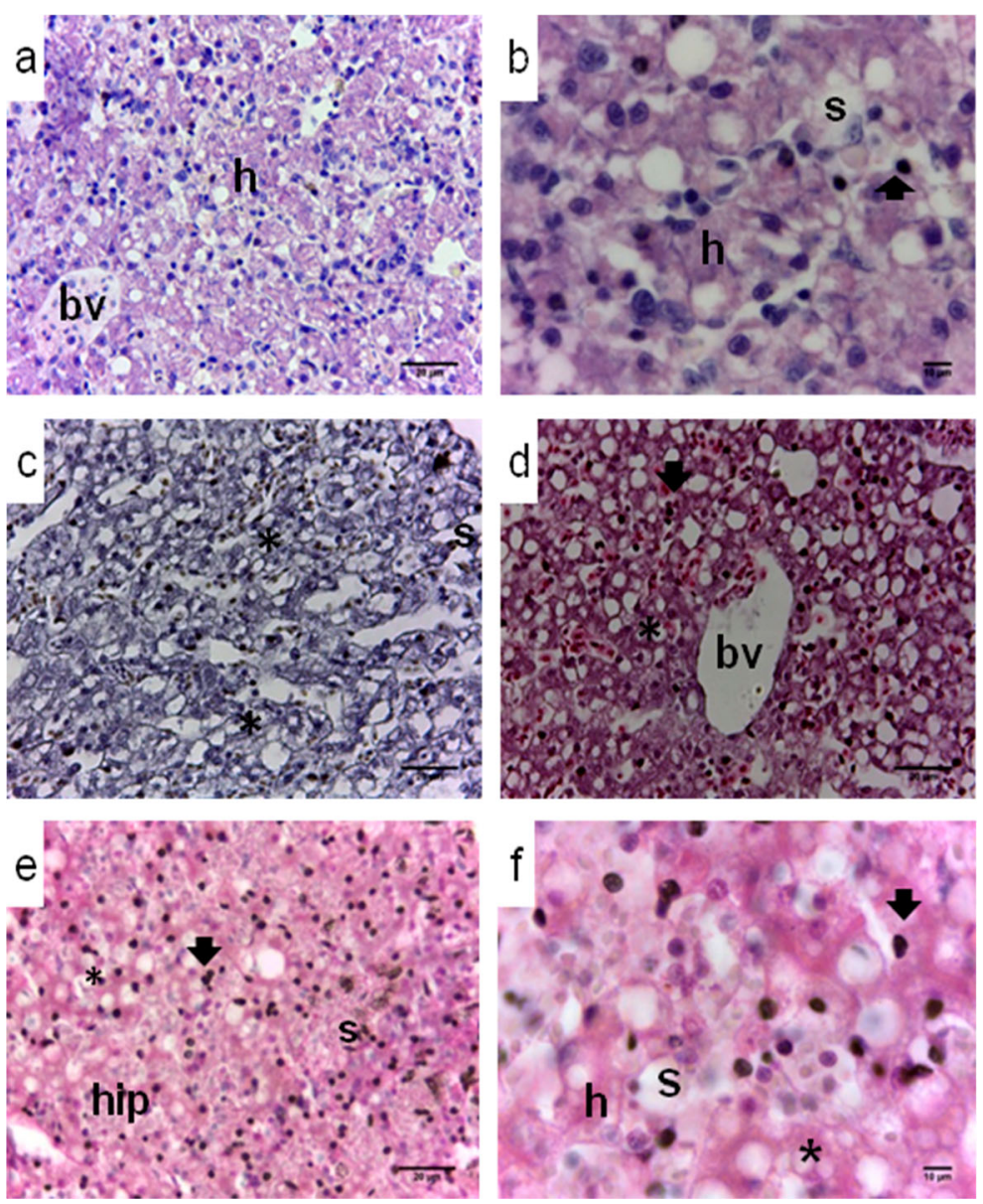

$\mathrm{D}$ in water bodies are known (Ruiz de Arcaute et al. 2016). According to Mesak et al. (2018), it is necessary to adopt high and consequently non-realistic concentrations for bioassays. High concentrations can be useful to understand the mechanism of action of chemicals on test organisms (Islam et al. 2018). In our study, this information is relevant due to the lack of information about the acute and chronic exposure to this herbicide.

According to the USEPA (2005), the acute toxicity to aquatic organisms varies widely among the different forms of 2,4-D. In fish, the 2,4-D acid and amine salt have $\mathrm{LC} 0_{96 \mathrm{~h}}$ values ranging from 63 to $2780 \mathrm{mg} / \mathrm{L}$ (Cattaneo et al. 2008; Fairchild et al. 2008, 2009; Ruiz de Arcaute et al. 2016; Sarikaya and Yilmaz 2003; USEPA 2005). Exposure to the 2,4-D commercial herbicide DMA® within the $252-756 \mathrm{mg} / \mathrm{L}$ range for 48 and $96 \mathrm{~h}$ has been found to increase the genetic damage in Cnesterodon decemmaculatus (Pisces, Poeciliidae) (Ruiz de Arcaute et al. 2016), with a LC50 $96 \mathrm{~h}$ value of $1008 \mathrm{mg} / \mathrm{L}$ of 2,4-D.
The $\mathrm{LC} 50_{96 \mathrm{~h}}$ for $P$. albonotatus tadpoles at GS $25 \pm 1$ was $350 \mathrm{mg} / \mathrm{L}$ of 2,4-D Amina Zamba®, similar to values recorded for other anuran species. By using FETAX (frog embryo teratogenic assay Xenopus), Morgan et al. (1996) determined LC50 values of 254 and > $270 \mathrm{mg} / \mathrm{L}$ in buffer and natural water, respectively. The LC50 $96 \mathrm{~h}$ values determined by Figueredo and Rodrigues (2014) for Rhinella marina and Physalaemus centralis tadpoles at GS 25 obtained after 2,4-D exposure were 282.84 (227.6-351.49) and 515.75 (456.66$582.48) \mathrm{mg} / \mathrm{L}$, respectively.

In anurans, data about the chronic toxicity of commercial products containing $2,4-\mathrm{D}$ as an active ingredient are relatively scarce (Coady et al. 2013; Figueredo and Rodrigues 2014). In the present study, we found that the chronic exposure to 2,4-D Amina Zamba® affected the survival of the tadpoles until metamorphosis. Survival decreased markedly from day 13 of exposure at the highest concentrations tested $(262.5 \mathrm{mg} / \mathrm{L})$, whereas at the other 


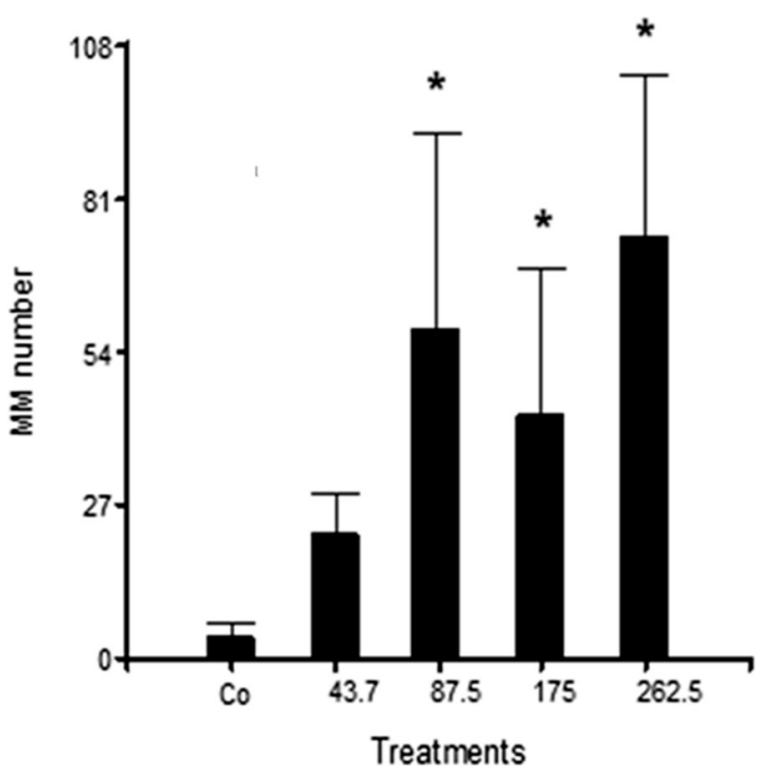

Fig. 6 Numbers of melanomacrophages expressed as mean \pm standard deviation in hepatic tissues of $P$. albonotatus tadpoles exposed to 2,4-D Amina Zamba ${ }^{\circledR}$ and control $(\mathrm{Co})$. The asterisks indicate significant differences from controls $(P<0.05)$

concentrations, the survival decreased more gradually after day 13 . We would like to point out that the increased mortality in controls after day 27 , respect treated 2,4-D Amina Zamba ${ }^{\circledR}$ tadpoles from $43.7 \mathrm{mg} /$ $\mathrm{L}$, may be due to inherent biological survival and acclimation of species that under laboratory conditions survive less than in natural conditions, indicating that effect of contaminant on P. albonotatus is important to studies at earlier stages or no more than 27 days as suggested in our study. The changes occurring during the larval phases of anurans are important because they can compromise the fitness and survival of the adult individual (Chelgren et al. 2006; Semlitsch et al. 2000), and the sublethal effect of aquatic contaminants may persist into subsequent life stages (Blaustein and Kiesecker 2002).

Several studies have shown a decrease in the tadpole body size after exposure to high concentrations of atrazine (Spolyarich et al. 2010; Zaya et al. 2011), but not after exposure to other herbicides (Coady et al. 2004, 2013; Velázquez et al. 2013). Physalaemus albonotatus tadpoles exposed to $43.75,87.5,175$, and $262.5 \mathrm{mg} / \mathrm{L}$ of 2,4-D Amina Zamba® showed no significant differences in body sizes (SVL, TL, and BW) compared to control. These results are in concordance with those of Mesak et al. (2018), and demonstrate that the body size cannot be directly related to the dose-dependent effect of the herbicide analyzed.

In amphibians, corticosteroids interact with the thyroid hormone, and several changes in this way can alter their metamorphosis (Denver 2009, 2013). In the present study, 2,4-D-treated tadpoles showed an acceleration in the development time and completed metamorphosis before control tadpoles. Other herbicides such as acetochlor in Rana pipiens (Cheek et al. 1999) and $X$. laevis (Crump et al. 2002) and atrazine in Rhinella arenarum tadpoles (Brodeur et al. 2013) also induced an acceleration of the metamorphosis. These authors have interpreted that the acceleration of metamorphosis is caused by a stimulation of the hypothalamicpituitary-interrenal axis mediated by the secretion of glucocorticoids as response to environmental stressors like xenobiotics. In addition, Figueredo and Rodrigues (2014) observed an acceleration of metamorphosis in Physalaemus centralis tadpoles treated with 128.87 and $257.87 \mathrm{mg} / \mathrm{L}$ of 2,4-D, possibly as a response to physiological stress. Until now, the effects of 2,4-D on the hypothalamic-pituitary-thyroid axis are not known and further studies are necessary to establish a relationship between the disruption of the thyroid hormone and the effect of the 2,4-D herbicide.

The morphological abnormalities in anuran tadpoles have also been linked with agrochemical exposures (Lajmanovich et al. 2003a, b; Lenkowski et al. 2008, 2010; Peltzer et al. 2011). In the present study, several sublethal effects on the larval morphology were observed in the treated tadpoles but not in control individuals. Several authors have concluded that 2,4-D is teratogenic only at concentrations higher than $50 \mathrm{mg} / \mathrm{L}$ (Cooke 1972; Meehan et al. 1974), whereas Morgan et al. (1996) found that natural water doses with 2,4-D caused minimal effects of frog embryos, even at $270 \mathrm{mg} / \mathrm{L}$. These results showed that high doses of 2,4-D are responsible for producing deleterious effects in anurans.

In this study, the most prevalent morphological abnormalities observed were oral disc malformations and intestinal abnormalities. A high prevalence of oral disc malformations was recorded at the highest concentrations of 2,4-D Amina Zamba® ${ }^{\circledR}$ (87.5, 175, and $262.5 \mathrm{mg} / \mathrm{L})$. Regarding morphological abnormalities, Pérez Iglesias et al. (2015) found that Pivot $\mathrm{H}^{\circledR}$ (an Imazethapyr-based herbicide) caused loss of queratodonts in relation to the herbicide concentration (0.41 to $2.72 \mathrm{mg} / \mathrm{L}$ ), whereas Rowe et al. (1996) found 
that the tadpoles of Rana catesbeiana collected in coal ash disposal sites contaminated with $\mathrm{As}, \mathrm{Cd}, \mathrm{Cu}, \mathrm{Se}$, and other contaminants had reduced number of labial teeth and deformations of labial papillae as compared to those collected in control sites. The malformations of oral morphology, like reductions of keratodonts, can affect the diet of tadpoles, and thus these tadpoles would be less active and would have reduced fitness, a fact that would consequently affect their survival (Pérez Iglesias et al. 2015). Furthermore, the treated tadpoles exposed to the higher concentrations also showed intestinal abnormalities. Lenkowski et al. (2010) demonstrated that $60-70 \mathrm{mg} / \mathrm{L}$ of $2,4-\mathrm{D}$ caused an increase in intestinal abnormalities and edemas in $X$. leavis tadpoles. This could be due to a disruption of a specific signaling pathway of organ and visceral morphogenesis, as demonstrated for atrazine in X. laevis tadpoles (Lenkowski and McLaughlin 2010). Retinoic acid signaling is essential in the development and function of various organ systems (Das et al. 2014; Lipscomb et al. 2006), but this pathway can be disrupted by certain environmental pollutants and can cause malformations during development (Inoue et al. 2010). However, the interference of the retinoic acid pathway caused by 2,4-D has not been demonstrated.

The liver is the primary site of metabolism, detoxification, and excretion of toxic substances (Hall and Gyton 2011) and one of the main organs affected by exposure to pollutants. In Piaractus mesopotamicus exposed to atrazine, Pereira de Paiva et al. (2017) found that the liver showed nuclear and cytoplasmic vacuolization, cytoplasmic hyaline inclusions, and necrosis, whereas in Bufo variabilis exposed to Carbaryl, Cakici (2015) found that the liver showed congestion, enlargement of sinusoids, vacuolization of hepatocytes, and a large number of MMs. In Pelophylax ridibundus (marsh frog) exposed to sublethal concentrations of the insecticide Talstar10EC, Paunescu et al. (2012) found hepatic lesions such as vacuolization and nuclear pyknosis of hepatocytes, dilation of Disse's space and sinusoid capillaries.

Histological biomarkers like MMs are useful as indicators of environmental pollution, particularly for sublethal and chronic effects of chemical agents (Bernet et al. 1999; Huespe et al. 2017; Passantino et al. 2013). MMs synthesize melanin, a protective pigment able to scavenge free radicals, and neutralize cations, protecting tissues from cytotoxic damage (Barni et al. 1999; Scalia et al. 1990). Loumbourdis and Vogiatzis (2002) described a marked increase in the number of MMs in Rana ridibunda after cadmium exposure, whereas other researchers demonstrated similar effects in adults of Rana (Pelophylax) ridibunda exposed to the insecticide Reldan 40EC (Paunescu et al. 2010), in Bufotestes variabilis exposed to carbaryl (Cakici 2015), in Leptodactylus latinasus exposed to glyphosate (Pérez Iglesias et al. 2016), and in Leptodactylus chaquensis exposed to chlorpyrifos (Huespe et al. 2017). Likewise, in Leptodactylus latrans tadpoles exposed to Roundup ${ }^{\circledR}$ Ultramax and glyphosate, Bach et al. (2018) observed histological alterations in the liver, such as lipidosis and hepatic congestion, and an increase in the number of MMs. In the present study, the P. albonotatus tadpoles chronically exposed to a 2,4-D formulation also showed hepatic tissue damage and MMs proliferation. Although the MMs proliferation did not show a dose-response relationship, in the highest concentrations tested (87.5, 175 , and $262.5 \mathrm{mg} / \mathrm{L}$ of 2,4-D Amina Zamba®) the MM numbers was significantly higher than control and than the low concentration tested. The increase in the number of hepatic MMs is related to the detoxification processes (Harraez and Zapata 1986) and to their role in immune functions (Steinel and Bolnick 2017) and can be used as biomarkers of environmental pollution (Stentiford et al. 2003).

Our results demonstrate the toxic effects of 2,4-D Amina Zamba ${ }^{\circledR}$ in $P$. albonotatus tadpoles. The survival of the tadpoles was affected progressively through the chronic assay period, and the morphological abnormalities observed in 2,4-D-treated tadpoles may influence their survival, metamorphosis, fitness, and swimming performance. The histological analysis of the liver and the increase in the number of MMs are useful for ecotoxicological studies using anurans tadpoles, and as biomarkers of 2,4-D exposure. Furthermore, it is necessary to know real data regarding the $2,4-\mathrm{D}$ concentrations in different environments, and more studies are necessary to prevent the possible damage that may suffer the species of anurans or others aquatic species that inhabit these environments.

Acknowledgments Authors are thankful to Dra. Victoria Eusebi for English review. We also thank to Dra. Cristina S. Zalazar (Institute of Technological Development for the Chemical Industry (INTEC)) for the chemical analysis of 2,4-D commercial formulation. To the Direccción de Recursos Naturales de la provincia de Corrientes for providing the collection permits. We 
also thank the anonymous reviewer for many valuable comments and suggestions.

Funding Information This work was supported in part by the Project Course of Action for Research and Science Promotion (CAI+D project $\left.N^{\circ} 045,2012\right)$, National Council for Scientific and Technical Research (CONICET, project PIP N 036, 2014).

\section{Compliance with Ethical Standards}

Ethical Standards Animals used in this research were treated according to the norms of ASIH-American Society of Ichthyologists and Herpetologists (2004), and the bioethics protocol and bioethical evaluations proposed by the Animal Ethical Committee of the Facultad de Bioquímica y Ciencias Biológicas, Universidad Nacional del Litoral (Res. $N^{\circ}$ : 388/06). http://wwwfbcb.unl.edu. ar/pages/investigacion/comite-de-etica.php.

Conflict of Interest The authors declare that they have no conflicts of interest.

Publisher's Note Springer Nature remains neutral with regard to jurisdictional claims in published maps and institutional affiliations.

\section{References}

Agius, C., \& Roberts, R. J. (2003). Melano-macrophage centres and their role in fish pathology. Journal of Fish Diseases, 26(9), 499-509.

Alford, R. A., \& Richards, S. J. (1999). Global amphibian declines: a problem in applied ecology. Annual Review of Ecology and Systematics, 30, 133-165.

Aronzon, C. M., Sandoval, M. T., Herkovits, J., \& PerezColl, C. S. (2011). Stage-dependent toxicity of 2,4dichlorophenoxyacetic on the embryonic development of a South American toad Rhinella arenarum. Environmental Toxicology, 26, 373-381.

ASIH, HL, SSAR, (2004). American Society of Ichthyologists and Herpetologists. Guidelines for use of live amphibians and reptiles in field and laboratory research. http://asih. org/sites/default/files/documents/resources/ guidelinesherpsresearch2004.pdf/. Accessed 20 May 2018.

Attademo, A. M., Peltzer, P. M., Lajmanovich, R. C., Cabagna, M., \& Fiorenza, G. (2007). Plasma B-esterases and glutathione S-transferase activities in the toad Chaunus schneideri (Amphibia, Anura) inhabiting rice agroecosystems of Argentina. Ecotoxicology, 16(8), 533-539.

Attademo, A. M., Peltzer, P. M., Lajmanovich, R. C., Cabagna-Zenklusen, M., Junges, C. M., Lorenzatti, E., Aró, C., \& Grenón, P. (2015). Biochemical changes in certain enzymes of Lysapsus llimellum (Anura: Hylidae) exposed to chlorpyrifos. Ecotoxicology and Environmental Safety, 113, 287-294.

Bach, N. C., Marino, D. J. G., Natale, G. S., \& Somoza, G. M. (2018). Effects of Glyphosate and its commercial formulation, Roundup ${ }^{\circledR}$ Ultramax, on liver histology of tadpoles of the Neotropical frog, Leptodactylus latrans (Amphibia: Anura). Chemosphere, 202, 289-297.

Barni, S., Bertone, V., Croce, A. C., Bottiroli, G., Bernini, F., \& Gerzeli, G. (1999). Increase in liver pigmentation during natural hibernation in some amphibians. Jornal of Anatomy, $195,19-25$.

Berger, G., Graef, F., \& Pfeffer, H. (2013). Glyphosate applications on arable fields considerably coincide with migratins amphibians. Scientific Reports, 3, 2622.

Bernet, D., Schmidt, H., Meier, W., Burkhardt-Holm, P., \& Wahli, T. (1999). Histopathology in fish: proposal for a protocol to assess aquatic pollution. Journal of Fish Diseases, 22(1), 2534.

Blaustein, A. R., \& Kiesecker, J. M. (2002). Complexity in conservation: lessons from the global decline of amphibian populations. Ecology Letters, 5, 597-608.

Boone, M. D. (2008). Examining the single and interactive effects of three insecticides on amphibian metamorphosis. Environmental Toxicology and Chemistry, 27(7), 15611568.

Brodeur, J. C., Sassone, A., Hermida, G. N., \& Codugnello, N. (2013). Environmentally-relevant concentrations of atrazine induce non-monotic acceletarion of developmental rate and increased size at metamorphosis in Rhinella arenarum tadpoles. Ecotoxicology and Environmental Safety, 92, 10-17.

Bruhl, C. A., Schmidt, T., Pieper, S., \& Alscher, A. (2013). Terrestrial pesticide exposure of amphibians: an underestimated cause of global decline? Scientific Reports, 3,1135 .

Cakici, O. (2015). Histopathologic changes in liver and kidney tiasues induced by carbaryl in Bufotestes variabilis (Anura: Bufonidae). Experimental and Toxicology Pathology, 67, 237-343.

Canadian Water Quality Guidelines for the Protection of Aquatic Life (Freshwater, Marine). (2014). Canadian Council of Ministers of the Environment. http://st-ts.ccme.ca/en/index. html. Accesed 02 Febrary 2018.

Carey, C., \& Bryant, C. J. (1995). Possible interrelations among environmental toxicants, amphibian development, and decline of amphibian populations. Environmental Health Perspectives, 103, 13-17.

Cattaneo, R., Loro, V. L., Spanevello, R., Silveira, F. A., Luz, L., Miron, D. S., Fonseca, M. B., Moraes, B. S., \& Clasen, B. (2008). Metabolic and histological parameters on silver catfish (Rhamdia quelen) exposed to commercial formulation of 2,4-diclorophenooxiacetic acid (2,4D) herbicide. Pesticide Biochemistry and Physiology, 92, 133-137.

Charles, J. M., Hanley, T. R. J., Wilson, R. D., van Ravenzwaay, B., \& Bus, J. S. (2001). Developmental toxicity studies in rats and rabbits on 2,4-dichlorophenoxyacetic acid and its forms. Toxicology Science, 60(1), 121-131.

Cheek, A. O., Ide, C. F., Bollinger, J. E., Rider, C. V., \& McLachlan, J. A. (1999). Alteration of leopard frog (Rana pipiens) metamorphosis by the herbicide acetochlor. Archives of Environmental Contamination and Toxicology, 37(1), 7077.

Chelgren, N. D., Rosenberg, D. K., Heppel, S. S., \& Gitelman, A. I. (2006). Carryover aquatic effects on survival of metamorphic frogs during pond migrations. Ecological Applications, 16(1), 250-261. 
Coady, K., Marino, T., Thomas, J., Sosinski, L., Neal, B., \& Hammond, L. (2013). An evaluation of 2,4dichlorophenoxyacetic acid in the amphibian metamorphosis assay and the fish short-term Reproductionn assay. Ecotoxicology and Environmental Safety, 90, 143-150.

Coady, K. K., Murphy, M. B., Vulleneuve, D. L., Hecker, M., Jones, P. D., Carr, J. A., Salomon, K. R., Smith, E. E., Van der Kraak, G., Kendall, R. J., \& Giesy, J. P. (2004). Effects of atrazine on metamorphosis, growth, and gonadal development in the Green Frog (Rana clamitans). Journal of Toxicology and Environmental Health A, 67, 91-957.

Cooke, A. S. (1972). The effect of DDT, Dieldrin and 2,4D on amphibian spawn and tadpoles. Evironmental Pollution, 3(1), 51-68.

Crump, D., Werry, K., Veldhoen, N., Van Aggelen, G., \& Helbing, C. C. (2002). Exposure to the herbicide acetochlor alters thyroid hormone-dependent gene expression and metamorphosis in Xenopus laevis. Environmental Health Perspectives, 110(12), 1199-1205.

Dann, A.B., (2009). The effects of Triclosan, 2,4-d, and their byproducts on the adrenocortical cells of rainbow trout. Thesis submitted to the School of Graduate Studies of the University of Lethbridge in partial fulfillment of the requirements of the degree. Department of Biological Sciences University of Lethbridge, Lethbridge, Alberta, Canada. https://www.uleth. ca/dspace/bitstream/handle/10133/3154/dann,\%20andrea. pdf; sequence $=1$

Das, B. C., Thapa, P., Karki, R., Das, S., Mahapatra, S., Liu, T., Torregroza, P., Wallace, D. P., Kambhampati, S., \& Van eldhuizen, P., Verma, A., Ray, S.K., Evans, T. (2014). Retinoic acid signaling pathways in development and diseases. Bioorganic \& Medicinal Chemistry, 22(2), 673-683.

Davidson, C., Shaffer, H. B., \& Jennings, M. R. (2002). Spatial tests of the pesticide drift, habitat destruction, UV-B, and climate-change hypotheses for California amphibian declines. Conservation Biology, 16(6), 1588-1601.

Davidson, C., \& Knapp, R. A. (2007). Multiple stressors and amphibian declines: dual impacts of pesticides and fish on yellow-legged frogs. Ecological Applications, 17(2), 587597.

Denver, R. J. (2009). Stress hormones mediate environmentgenotype interactions during amphibian development. General and Comparative Endocrinology, 164, 20-31.

Denver, R. J. (2013). Neuroendocrinoloy of amphibian metamorphosis. Current Topics in Developmental Biology, 103, 195227.

Fairchild, J.F., Allert, A., Sappington, L.S., Nelson, K.J., Valle, J., (2008). Using accelerated life testing procedures to compare the relative sensitivity of rainbow trout and the threatened bull trout to three commonly-used rangeland herbicides (picloram, 2,4-D and clopyralid). Environmental Toxicology Chemistry, 27(3), 623630.

Fairchild, J. F., Feltz, K. P., Allert, A. L., Sappington, L. C., Nelson, K. J., \& Valle, J. A. (2009). An ecological risk assessment of the exposure and effects of 2,4-D acid to rainbow trout (Onchorhyncus mykiss). Archives of Environmental Contamination and Toxicology, 56, 754-760.

Figueredo, J., \& de Jesus Rodrigues, D. (2014). Effects of four types of pesticides on survival, time and size to metamorphosis of two species of tadpoles (Rhinella marina and
Physalaemus centralis) from the southern Amazon, Brazil. Herpetological Journal, 24, 7-15.

Franco, A., \& Trapp, S. (2010). A multimedia activity model for ionizable compounds: validation study with 2,4dichlorophenoxyacetic acid, aniline, and trimethoprim. Environmental Toxicology and Chemistry, 29, 789-799.

Gonzalez, J. M., Smith, D. R., Livingston, S., WarnemuendePappas, E., \& Zwonitzer, M. (2016). Blind inlets: conservation practices to reduce herbicide losses from closed depressional areas. Journal of Soils and Sediments, 16, 1921-1932.

Gosner, K. L. (1960). A simplified table for staging anuran embryos and larvae, with notes on identification. Herpetologica, 16, 183-190.

Glozier, N. E., Struger, J., Cessna, A. J., Gledhill, M., Rondeau, M., Ernst, W. R., Sekela, M. A., Cagampan, S. J., Sverko, E., \& Murphy, C. (2012). Occurrence of glyphosate and acidic herbicides in select urban rivers and streams in Canada, 2007. Environmental Science and Pollution Research, 19, 821-834.

Hailey, A., Sooko, N., Mohammed, A., \& Khan, A. (2006). Factors affecting tadpoles growth: develompent of rearing system for the Neotropical leptodactylid Physalaemus pustulosus for ecotoxicological studies. Applied Herpetology, 3, 111-128.

Hall, J., \& Guyton, A. (2011). Textbook of medical physiology (12th ed.). Philadelphia: Saunders/Elservier.

Hamilton, M. A., Russo, R. C., \& Thurston, R. V. (1977). Trimmed Spearman-Karber method for estimating median lethal concentrations in toxicity bioassays. Environmental Science \& Technology, 11, 714-719.

Harraez, M. P., \& Zapata, A. G. (1986). Structure and function of the melano-macrophage centres of the goldfish Carassius auratus. Veterinary Immunology and Immunopathology, 12(1-4), 117-126.

Hayes, T. B., Collins, A., Lee, M., Mendoza, M., Noriega, N., Stuart, A. A., \& Vonk, A. (2002). Hermaphroditic, demasculinized frogs after exposure to the herbicide atrazine at low ecologically relevant doses. Proceedings of the National Academy of Sciences of the United States of America, 99(8), 5476-5480.

Hayes, T., Haston, K., Tsui, M., Hoang, A., Haeffele, C., \& Vonk, A. (2003). Atrazine induced hermaphroditism at $0.1 \mathrm{ppb}$ in American leopard frogs (Rana pipiens): laboratory and field evidence. Environmental Health Perspectives, 111(4), 568575.

Hayes, T. B., Stuart, A. A., Mendoza, M., Collins, A., Noriega, N., Vonk, A., Johnston, G., Liu, R., \& Kpodzo, D. (2006a). Characterization of atrazine-induced gonadal malformations in African clawed frogs (Xenopus laevis) and comparisons with effects of an androgen antagonist (cyproterone acetate) and exogenous estrogen (17 b-estradiol): support for the demasculinization/feminization hypothesis. Environmental Health Perspectives, 114, 134-141.

Hayes, T. B., Case, P., Chui, S., Chung, D., Haeffele, C., Haston, K., Lee, M., Phoung Mai, V., Marjuoa, Y., Parker, J., \& Tsui, M. (2006b). Pesticide mixtures, endocrine disruption, and amphibian declines: are we underestimating the impact? Environmental Health Perspectives, 114(1), 40-50. 
Hayes, T. B., \& Wu, T. H. (1995). Role of corticosterone in anuran metamorphosis and potential role in stress-induced metamorphosis. Netherland Journal of Zoology, 45(1-2), 107-109.

Huespe, I., Cabagna-Zenklusen, M., Curi, L. M., Peltzer, P. M., Attademo, M. A., Villafañe, N., \& Lajmanovich, R. C. (2017). Liver melanomacrophages and gluthation Stransferase activity in Leptodactylus chaquensis (Anura: Leptodactylidae) as biomarkers of oxidative stress due to Chlorpirifos exposition. Acta Biologica Colombiana, 22(2), 234-237.

IARC. International Agency for Research on Cancer, (2015). Monographs on the evaluation of carcinogenic risk of chemicals to man. Some organochlorine insecticides and some chlorphenoxy herbicides. International Agency for Research on Cancer, Lyon. https://monographs.iarc.fr/. Accesed 08 March 2018.

Inoue, D., Sei, K., \& Ike, M. (2010). Disruption of retinoic acid receptor signaling by environmental pollutants. Journal of Health Science, 56(3), 221-230.

IUCN (2017), The IUCN red list of threatened species. Version 2017-3. http://www.iucnredlist.org. Accesed 12 December 2017.

Islam, F., Wang, J., Muhammad, F., Jhan, M. A., Xu, M. S. S., Zhu, L., Zhao, J., Muños, M., Li, S., \& Zhou, Q. X. W. (2018). Potential impact of the herbicide 2,4-diclorophenoxyacetic acid on human and ecosystems. Environment International, 111, 332-351.

Jantawongsri, K., Thammachoti, P., Kitana, J., Khonsue, W., Varanusupakul, P., \& Kitana, N. (2013). Altered immune response of the rice frog Fejervarya limnocharis living in agricultural area with intensive herbicide utilization at Nan Province, Thailand. Environmental Asia, 8(1), 68-74.

Krishnamurthy, S. V., \& Smith, G. R. (2011). Combined effects of malathion and nitrate on early growth, abnormalities, and mortality of wood frog (Ranas sylvatica) tadpoles. Ecotoxicology, 20(6), 1361-1367.

Lajmanovich, R. C., Sandoval, M. T., \& Peltzer, P. M. (2003a). Induction of mortality and malformation in Scinax nasicus tadpoles exposed by glyphosate formulations. Bulletin of Environmental Contamination and Toxicology, 70(3), 612618.

Lajmanovich, R. C., Lorenzatti, E., Maitre, M. I., Enrique, S., \& Peltzer, P. M. (2003b). Comparative acute toxicity of the comercial herbicides glyphosate to neotropical tadpoles Scinax nasicus (Anura: Hylidae). Fresenius Environmental Bulletin, 12(4), 364-367.

Lajmanovich, R. C., Attademo, M. A., Peltzer, P. M., Junges, C. M., \& Cabagna, M. C. (2011). Toxicity of four herbicide formulations with glyphosate on Rhinella arenarum (Anura: Bufonidae) tadpoles: B-esterases and glutathione Stransferase inhibitors. Archives of Environmental Contamination and Toxicology, 60(4), 681-689.

Lajmanovich, R. C., Attademo, A. M., Simoniello, M. F., Poletta, G. L., Junges, C. M., Peltzer, P. M., Grenon, P., \& CabagnaZenklusen, M. C. (2015). Harmful effects of the dermal intake of commercial formulations containing chlorpyrifos, 2, 4-D, and glyphosate on the common toad Rhinella arenarum (Anura: Bufonidae). Water, Air, and Soil Pollution, 36, 226-427.

Lenkowski, J. R., Reed, J. M., Deininger, L., \& McLaughlin, K. A. (2008). Perturbation of organogénesis by the herbicide atrazine in the amphibian Xenopus laevis. Environmental Health Perspectives, 116(2), 223-230.

Lenkowski, J.R., Sanchez-Bravo, G., McLaughlin, K.A., (2010). Low concentrations of atrazine, glyphosate, 2,4-dichloro phenoxy acetic acid,and triadimefon exposures have diverse effects on Xenopus laevis organ morphogenesis. Journal of Environmental Sciences, 22(9), 1305-1308.

Lenkowski, J. R., \& McLaughlin, K. A. (2010). Acute atrazine exposure disrupts matrix metalloproteinasas and retinoid signaling during organ morphogenesis in Xenopus laevis. Journal of Applied Toxicology, 30(6), 582-589.

Lipscomb, K., Schmitt, C., Sablyak, A., Yoder, J. A., \& NasconeYoder, N. (2006). Role for retinoid signaling in left-right asymmetric digestive organ morphogenesis. Developmental Dynamics, 235(8), 2266-2275.

Lilienfeld, D., \& Gallo, M. (1989). 2,4,5-T, and 2,3,7,8-TCDD: an overview. Epidemiologic Reviews, 11, 28-36.

Loumbourdis, N. S., \& Vogiatzis, A. K. (2002). Impact of cadmium on liver pigmentary system of the frog Rana ridibunda. Ecotoxicology and Environmental Safety, 53(1), 52-58.

Mann, R. M., Hyne, R. V., Choung, C. B., \& Wilson, S. P. (2009). Amphibians and agricultural chemicals: Review of the risks in a complex environment. Environmental Pollution, 157(11), 2903-2927.

Marcato, A. C. C., Souza, C. P., \& Fontanetti, C. S. (2017). Herbicide 2,4D: a review of toxicity on non-Trget organism. Water, Air, and Soil Pollution, 228, 120.

Marco, A., Cash, D., Belden, L. K., \& Blaustein, A. R. (2001). Sensitivity to urea fertilization in three amphibian species. Archives of Environmental Contamination and Toxicology, 40, 406-409.

Meehan, W., Norris, L., \& Sears, H. (1974). Toxicity of various formulations of 2,4-D to salmonids in southeast Alaska. Journal of the Fisheries Research Board of Canada, 31(4), 480-485.

Mesak, C., Oliveira Mendes, B., Oliveira Ferreira, R., \& Malafaia, G. (2018). Mutagenic assessment of Lithobates catesbeianus tadpoles exposed to the 2,4D herbicide in a simulated realistic scenario. Environmental Science and Pollution Research, 25(15), 15235-15244.

Metts, B. S., Hopkins, W. A., \& Nestor, J. P. (2005). Interaction of an insecticide with larval density in pond-breeding salamanders (Ambystoma). Freshwater Biology, 50(4), 685-696.

Morgan, M. K., Scheuerman, P. R., Bishop, C. S., \& Pyles, R. A. (1996). Teratogenic potential of antrazine and 2,4-D using FETAX. Journal of Toxicology and Environmental Health, 48(2), 151-168.

Nikoloff, N., Natale, G. S., Marino, D., Solonesky, S., \& Larramendy, M. (2014). Flurochloridone-based herbicides induced genotoxicity effects on Rhinella arenarum tadpoles (Anura: Bufonidae). Ecotoxicology and Environmental Safety, 100, 275-281.

Oztas, H., Ozdemir, C., \& Kalipci, E. (2011). Investigation of ecotoxicological effects of 2,4-D acid herbicide on the ecosystem. World Applied Sciences Journal, 14, 126-135.

Palma, G., Sánchez, A., Olave, Y., Encina, F., Palma, R., \& Barra, R. (2004). Pesticides levels in surface waters in an agricultural-forestry basin in Southern Chile. Chemosphere, 57, 763-770.

Passantino, L., Santamaria, N., Zupa, R., Pousis, C., Garofalo, R., Cianciotta, A., Jirillo, E., Acone, F., \& Corriero, A. (2013). 
Liver melanomacrophage centres as indicators of Atlantic bluefin tuna, Thunnus thynnus L. well-being. Journal of Fish Diseases, 37(3), 241-250.

Paunescu, A., Ponepal, C. M., Drghici, O., \& Marinescu, A. G. (2010). Liver histopathologic alterations in the frog Rana (Pelophylax) ridibunda induce by the action of Reldan 40EC insecticide. Analele Universitatii din Oradea Fascicula Biologie, 17(1), 166-169.

Paunescu, A., Ponepal, C. M., Grigorean, V. T., \& Popescu, M. (2012). Histopathological changes in the liver and kidney tissues of marsh frog (Pelophylax ridibundus) induced by the action of Talstar 10EC insecticide. Analele Universitatii din Oradea Fascicula Biologie, 19(1), 5-10.

Peltzer, P. M., Lajmanovich, R. C., Attademo, A. M., Junges, C. M., Cabagna, Z., Repetti, M. C., Sigrist, R., \& Beldoménico, H. M. (2013). Effect of exposure to contaminated pond sediments on survival, development, and enzyme and blood biomarkers in veined tree frog (Trachycephalus typhonius) tadpoles. Ecotoxicology and Environmental Safety, 98, 142151.

Peltzer, P. M., Lajmanovich, R. C., Sanchez-Hernandez, J. C., Cabagna, M., Attademo, A. M., \& Bassó, A. (2008). Effects of agricultural pond eutrophication on survival and health status of Scinax nasicus tadpoles. Ecotoxicology and Environmental Safety, 70(1), 185-197.

Peltzer, P. M., Lajmanovich, R. C., Sanchez, L. C., Attademo, A. M., Junges, C. M., Bionda, C. L., Martino, A. L., \& Bassó, A. (2011). Morphological abnormalities in wild amphibian populations from the mid-eastern of Argentina. Herpetological Conservation and Biology, 6, 432-442.

Pérez Iglesias, J. M., Franco-Belussi, L., Moreno, L., Tripole, S., De Oliveira, C., \& Natale, G. S. (2016). Effects of glyphosate on hepatic tissue evaluating melanomacrophages and erythrocytes responses in Neotropical anuran Leptodactylus latinasus. Environmental Science and Pollution Research, 23(10), 9852-9861.

Pérez Iglesias, J. M., Soloneski, S., Nikoloff, N., Natale, G. S., \& Larramendy, M. L. (2015). Toxic and genotoxic effects of the imazethapyr-based herbicide formulation Pivot $H ®$ on Montevideo tree frog Hypsiboas pulchellus larvae (Anura, Hylidae). Ecotoxicology and Environmental Safety, 119, 1524.

Pereira de Paiva, P., Cruz Delcorso, M., Matheus, V. A., do Nascimento de Queiroz, S. C., Collares-Buzato, C. B., \& Arana, S. (2017). Acute toxicity of commercial atrazine in Piaractus mesopotamicus: histopathological, ultrastructural, molecular, and genotoxic evaluation. Veterinary World, 10, $1008-1019$.

Punzo, F. (2005). Effects of insecticide (Carbaryl) exposure on activity and swimming performance of tadpoles of the Rio Grande leopard frog, Rana berlandieri (Anura: Ranidae). Texas Journal of Science, 57(3), 263-272.

Relyea, R. A. (2005). The lethal impacts of Roundup and predatory stress on six species of North American tadpoles. Archives of Environmental Contamination and Toxicology, 48(3), 351-357.

Relyea, R. A., \& Hoverman, J. T. (2006). Assessing the ecology in ecotoxicology: a review and synthesis in freshwater systems. Ecology Letters, 9(10), 1157-1171.

Rodriguez, E. M., \& Amin, O. A. (1991). Acute toxicity of parathion and 2,4-D to larval and juvenile stage of
Chasmagnatuthus granulata (Decapoda, Brachyura). Bulletin of Environmental Contamination and Toxicology, 47, 634-640.

Rowe, C. L., Kinney, O. M., Fiori, A. P., \& Congdon, J. D. (1996). Oral deformities in tadpoles (Rana catesbeiana) associated with coal ash deposition: effects on grazing ability and growth. Freshwater Biology, 36, 723-730.

Ruiz de Arcaute, C., Soloneski, S., \& Larramendy, M. L. (2016). Toxic and genotoxic effects of the2,4-dichlorophenoxyacetic acid (2,4-D)-based herbicide on the Neotropical fish Cnesterodon decemmaculatus. Ecotoxicology and Environmental Safety, 128, 222-229.

Ryan, T. J., Scott, C. M., \& Douthitt, B. A. (2007). Sub-lethal effects of 2,4-D exposure on golf course amphibians. USGA Turfgrass and Environmental Research Online., 5, 1-14.

Sánchez, L. C., Lajmanovich, R. C., Peltzer, P. M., Manzano, A. S., Junges, C. M., \& Attademo, A. M. (2014). First evidence of the effects of agricultural activities on gonadal form and function of Rhinella fernandezae and Dendropsophus sanborni (Amphibia: Anura) from Entre Rios, Province, Argentina. Acta Herpetologica, 9, 75-88.

Santos, L. R. S., Franco-Belussi, L., Zieri, R., Borges, R. E., \& Oliveira, C. (2014). Effects of thermal stress on hepatic melanomacrophages of Eupemphix nattereri (Anura). Anatomical Research, 297(5), 864-875.

Sarikaya, M., \& Yilmaz, M. (2003). Investigation of acute toxicity and the effect of 2,4-D (2,4-dichlorophenoxyacetic acid) herbicide on the behavior of the common carp (Cyprinus carpio L., 1758; Pisces, Cyprinidae). Chemosphere, 52, 195-201.

Semlitsch, R., Bridges, C. M., \& Welch, A. M. (2000). Genetic variation and a fitness tradeoff in the tolerance of gray treefrog (Hyla versicolor) tadpoles to the insecticide Carbaryl. Oecologia, 125, 179-185.

Sayed, A. H., \& Younes, H. A. M. (2017). Melanomacrophage centers in Clarias gariepinus as an immunological biomarker for toxicity of silver nanoparticles. Journal of Microscopy and Ultrastructure, 5, 97-104.

Scalia, M., Geremia, E., Corsaro, C., Santoro, C., Baratta, D., \& Sichel, G. (1990). Lipid peroxidation in pigmented and unpigmented liver tissue: protective role of melanin. Pigment Cell Research, 3(2), 115-119.

Spolyarich, N., Hyne, R., Wilson, S., Palmer, C., \& Byrne, M. (2010). Growth, development and sex ratios of Spotted Mars Frog (Limnodynastes tasmaniensis) larvae exposed to atrazine and an herbicide mixture. Chemosphere, 78, 807-813.

Stebbins-Boaz, B., Fortner, K., Frazier, J., Piluso, S., Pullen, S., Rasar, M., Reid, W., Sinclair, K., \& Winger, E. (2004). Oocyte Maturtion in Xenopus laevis is blocked by the hormonal herbicide, 2,4-dichlorophenoxy acetic acid. Molecular Reproduction and Development, 67(2), 233-242.

Steinel, N. C., \& Bolnick, D. I. (2017). Melanomacrophage centers as a histological indicator of immune function in fish and other poikilotherms. Frontiers in Immunology, 8, 827.

Stentiford, G. D., Longshaw, M., Lyons, B. P., Jones, G., Green, M., \& Feist, S. W. (2003). Histopathological biomarkers in estuarine fish species for the assessment of biological effects of contaminants. Marine Environmental Research, 55(2), 137-159.

Storrs, S. I., \& Semlitsch, R. D. (2008). Variation in somatic and ovarian development: predicting susceptibility of amphibians 
to estrogenic contaminants. General and Comparative Endocrinology, 156(3), 524-530.

Stuart, S. N., Chanson, J. S., Cox, N. A., Young, B. E., Rodrigues, A. S. L., Fischman, D. L., \& Waller, R. W. (2004). Status and trends of amphibian declines and extinctions worldwide. Science, 306(5702), 1783-1786.

Stuart, S.N., Hoffmann, M., Chanson, J.S., Cox, N.A., Berridge, R.J., Ramani, P., Young, B.E., (2008). Threatened amphibians of the world. Lynx editions, Barcelona; IUCN, Gland, Switzerland; and Conservation International, Arlington, Virginia, USA.

Teplitsky, C., Piha, H., Laurila, A., \& Merila, J. (2005). Common pesticide increases costs of antipredator defenses in Rana temporaria tadpoles. Environmental Science \& Technology, 39(16), 6079-6085.

USEPA. United States Environmental Protection Agency., (2005). Reregistration eligibility decision for 2,4-D.). EPA 738-R-05002. http:// nepis.epa.gov/Exe/ZyPDF.cgi/2000E8DY. PDF?Dockey $1 / 42000 E 8 D Y$. Accesed 11 November 2017.

Van der Oost, R., Beyer, J., \& Vermeulen, N. P. (2003). Fish bioaccumulation and biomarkers in environmental risk assessment: a review. Environmetal Toxicology and Pharmacology, 13(2), 57-149.

Velásquez, T. M. T., Montes Rojas, C. M., \& Bernal Bautista, M. H. (2013). Efectos letales y subletales del Glifosayo (Roundup ${ }^{\circledR}$ activo) en embriones de anuros colombianos. Acta Biologica Colombiana, 18, 271-278.

Waite, D. T., Cessna, A. J., Grover, R., Kerr, L. A., \& Snihura, A. D. (2002). Environmental concentrations of agricultural herbicides: 2,4-dd and triallate. Journal of Environmental Quality, 31(1), 129-144.

Wauchope, R. D., Buttler, T. M., Hornsby, A. G., AugustijnBeckers, P. W., \& Burt, J. P. (1992). The SCS/ARS/CES pesticide properties database for environmental decisionmaking. Reviews of Environmental Contamination and Toxicology, 123, 1-55.

Wake, D.B., Vredenburg, V.T., (2008). Are we in the midst of the sixth mass extinction? A view from the world of amphibians. Proceedings of the National Academic of Sciences, 105, 11466-11473.
Widder, P. D., \& Bidwell, J. (2008). Tadpole size, cholinesterase activity, and swim speed in four frog species after exposure to sub-lethal concentrations of chlorpyrifos. Aquatic Toxicology, 88(1), 9-18.

Wilson, R. D., Geronimo, J., \& Armbruster, J. A. (1997). 2,4-D dissipation in field soils after applications of 2,4-D dimethylamine salt and 2,4-D 2-ethylhexyl ester. Environmental Toxicology and Chemistry, 16, 1239-1246.

WHO. World Health Organization, International Programme on Chemical Safety \& WHO Task Group on Environmental Health Criteria for 2,4-Dichlorophenoxyacetic Acid (2,4-D: Environmental Aspects)., (1989). 2,4-Dichlorophenoxyacetic acid (2,4-D : environmental aspects / published under the joint sponsorship of the United Nations Environment Programme, the International Labour Organisation, and the World Health Organization. Geneva: World Health Organization. http://www.who.int/iris/handle/10665/40019. Accesed 15 March 2018.

WHO. World Health Organization., (2009). The WHO recommended classification of pesticides by Hazard 1. World Health Organization, Geneva, Italy. http://apps.who. int/iris/handle/10665/44271? locale=es. Accesed 15 March 2018.

Woudneh, M. B., Sekela, M., Tuominen, T., \& Gledhill, M. (2007). Acidic herbicides in surface waters of Lower Fraser Valley, British Columbia, Canada. Journal of Chromatografy A, 1139(1), 121-129.

Xie, L., Thrippleton, K., Irwin, M. A., Siemering, G. S., Mekebri, A., Crane, D., Berry, K., \& Schlenk, D. (2005). Evaluation of estrogenic activities of aquatic herbicides and surfactants using a rainbow trout vitellogenin assay. Toxicologicl Sciences, 87(2), 391-398.

Zaya, R. M., Amini, Z., Whitaker, A. S., Kohler, S. L., \& Ide, C. F. (2011). Atrazine exposure affects growth, body condition and liver health in Xenopus laevis tadpoles. Aquatic Toxicology, 104(3-4), 243-253.

Zimdahl, R. L. (1993). Fundamentals of weed science (fourth ed.). San Diego CA: Academic Press.

Zar, J. H. (1999). Biostatistical analysis (4th ed.). Upper Saddle River: Prentice Hall. 